\title{
RESPON SISWA TERHADAP PENGENALAN ANTIOKSIDAN DAN RADIASI PENGION ALAM (RADON) DI SDN DESA ARJASARI KABUPATEN BANDUNG
}

\author{
Ivhatry R.O.P.S ${ }^{\# 1}$, Azhari ${ }^{* 2}$,Suhardjo $\mathrm{S}^{*^{2}}$ \\ ${ }^{\# 1}$ Ilmu Kedokteran Dasar, Fakultas Kedokteran Universitas Padjadjaran \\ Jln. Prof. Eyckman no38,Pasteur Sukajadi Bandung Jawa Barat \\ ${ }^{1}$ ivhatryrizkyegmail.com \\ ${ }^{* 2,3}$ Departemen Radiologi Fakultas Kedokteran Gigi Universitas Padjadjaran \\ Jln. Sekeloa selatan no 1 kecamatan coblong, Bandung, Provinsi Jawa barat Indonesia \\ ${ }^{2}$ azhariefkg. unpad.ac.id \\ ${ }^{3}$ suhardjolf kg.unpad.ac.id
}

\begin{abstract}
Abstrak
Pengenalan dini antioksidan dan radon merupakan langkah dalam promosi kesehatan guna untuk meningkatkan pengetahuan, sikap, dan tindakan individu karena dapat berdampak pada kualitas hidup. Kegiatan ini dengan metode penyuluhan berprinsip edutaiment dan dibagikan kuesioner sebelum dan sesudah penyuluhan kepada siswa SDN Arjasari kelas IV,V dan VI yang direncanakan di bulan Juli 2017 dan di laksanakan pada bulan November 2017. Data yang diperoleh dari kuesioner dilakukan analisis statistika SPSS t-Test. Pengelompokan responden berdasarkan tingkat pengetahuan yang dimiliki menjadi 3 kategori responden berpengetahuan tinggi, sedang, dan rendah hasil respon siswa terhadap antioksidan dan radon sangat baik. Hal ini terlihat dari peningkatan pengetahuan pengetahuan siswa sebelum dan sesudah dilakukan penyuluhan edutaiment pada kelas IV V dan VI sebesar $2.19 \%$ pada kategori rendah, $19,08 \%$ pada kategori sedang dan $33,11 \%$ pada kategori tinggi. Siswa tertarik dengan dalam radiasi alam dan pengolahan jagung yang dapat menjadi konsumsi dan tambahan penghasilan bagi kedua orang tuanya. Oleh karena itu , perlu dilakukan penelitian lebih lanjut untuk meningkatkan pengetahuan siswa tentang cara meningkatkan kualitas hidup baik secara ekonomi dan sosial yang sesuai dengan Radon Mitigation Program yang di pelopori UNSCEAR dan EPA.
\end{abstract}

Kata kunci: Antioksidan, Pengetahuan, Radiasi Pengion Alami(Radon).

\section{PENDAHULUAN}

Desa arjasari adalah desa yang terletak di kaki gunung malabar kabupaten bandung dengan ketinggian sekitar 700-1000 meter dari permukaan laut. sebagian besar desa ini terdiri dari lahan pertanian dan pemukiman penduduk.sebagian besar mata pencaharian penduduk yaitu petani. jagung merupakan salah satu potensi sumber daya alam yang menjadi komoditas penghasilan warga desa arjasari.jagung berpotensi sebagai antioksidan alami. antioksidan adalah senyawa fitokimia yang dapat menghambat kerusakan dalam tubuh akibat radikal bebas [1]. Radikal bebas bersifat reaktif dan berbahaya jika kelebihan radikal bebas dalam tubuh sehingga diperlukan antioksidan yang berasal dari luar tubuh.bahan makanan yang berasal dari alam efektif dan aman sebagai antioksidan untuk meningkatkan kualitas hidup. salah satu penyebab adanya radikal bebas yaitu berasal dari radiasi.[1], [2] Radiasi dapat bersifat buatan dan alami. radiasi yang bersifat alami berasal dari alam yang memberikan kontribusi besar terhadap kesehatan. [3] Radon adalah salah satu radiasi alam yang berasal dari peluruhan bebatuan dan berasal dari tanah yang mempunyai unsur tidak berbau, tidak berwarna dan tidak berasa. fredrich ernst dorn pada tahun 1898 . pertama kali menemukan radon [4]-[6] dan salah satu penyumbang radiasi alam terbesar di bumi sebanyak 80\%. [3] Paparan gas ini dapat menyebabkan kanker paru paru pada sebagian besar penduduk dunia.[7] Hal ini didukung oleh who handbook on indoor radon (2009) bahwa adanya risiko yang ditimbulkan oleh radiasi pengion alam (radon) terhadap kesehatan dan dalam jangka panjang dan pada akhirnya akan berdampak pada kualitas hidup (quality of life/qol).[8]Akan tetapi, pengetahuan akan bahaya dari radiasi alam (radon) dan penanganannya yakni antioksidan belum bayak diketahui oleh masyarakat. salah satu metode untuk menyebarluaskan bahaya paparan radiasi radon dan penanganya dengan melakukan promosi kesehatan. promosi kesehatan ini dapat digunakan agar lebih menjamin peningkatan pengetahuan yang dapat mempengaruhi sikap dan perilaku seseorang.[9] Metode edutaiment ini lebih digunakan pada penelitian ini agar lebih dapat memperjelas materi yang ingin disampaikan.[10] Oleh karena itu, pemberian materi dengan metode edutaiment diharapkan lebih efisien dan lebih efektif hasilnya pada responden. 


\section{TARGET DAN LUARAN YANG DICAPAI}

Target dan luaran yang diharapkan adalah peningkatan kualitas promosi kesehatan usia dini dengan meningkatkan kesadaran danpengetahuan tentang kondisi lingkungan dan mengetahui cara pencegahan penyakit.

\section{METODE PENELITIAN}

Jenis penelitian ini menggunakan penelitian deskriptif analitik dengan metode survey dengan pendekatan potong lintang ( cross sectional) tentang pengetahuan radiasi pengion alam dan antioksidan yang diperlukan oleh tubuh. Sampel pada penelitian ini diambil dengan cara consecutive sampling, yaitu seluruh siswa yang datang ke SDN Arjasari Kabupaten Bandung. Kriteria inklusi pada penelitian ini adalah: peserta yang bisa membaca dan menulis dan merupakan siswa kelas IV,V dan VI SD Arjasari kabupaten Bandung yang mendapatkan penyuluhan mengenai radiasi pengion radon dan antioksidan. Kriteria eksklusi pada penelitian ini adalah Pasien yang tidak berasal dari SDN Arjasari dan berdomisili di luar Desa Arjasari . Berdasarkan Lemeshow, S. et al, (1997) Besar sampel penelitian ini dihitung dengan rumus

$$
\mathrm{n}=\frac{\mathrm{z}^{2} \mathrm{p}(1-\mathrm{p})}{\mathrm{d}^{2}}
$$

Keterangan :

$\mathrm{n}=$ Jumlah sampel yang dibutuhkan

$\mathrm{Z}=$ score $\mathrm{Z}$ berdasarkan nilai $\alpha$ yang diinginkan

$\alpha=$ derajat kepercayaan (95\%)

$\mathrm{d}=$ toleransi kesalahan

$\mathrm{p}=$ proporsi.

Total Populasi pada penelitian ini berjumlah 139 siswa (Notosiswoyo ,2014)

Penelitian ini direncanakan dimulai dari bulan Juli 2017 dan di laksanakan pada bulan Oktober 2017 setelah mengurus ke Dewan Komite Etik Kesehatan UNPAD. Kegiatan ini menggunakan metode penyuluhan dengan edutaiment yang dibuat oleh tim dosen berdasarkan hasil penelitian sebelumnya . Materi penyuluhan berisi definisi antioksidan dan produk tanaman yang berhubungan dengan komoditas utama Desa Arjasari yaitu Jagung. Pengenalan Jagung dan pengolahannya dan materi tentang radiasi alam pengion (radon) dijadikan sumber materi utama dalam penyuluhan dengan prinsip edutaiment.[10], [12] Sebelumnya, kuesioner dibagikan baik sebelum dan sesudah penyuluhan sebagai pre-test dan post-test untuk menilai pengetahuan siswa mengenai antioksidan dan radiasi alam. Kuesioner terdiri dari 20 pertanyaan dimana berisi 10 pertanyaan mengenai antioksidan alami dan 10 pertanyaan pengetahuan radiasi alam (radon). Setelah data terkumpul maka dilakukan tolak ukur pengetahuan mengenai norma penilaian yang berdasarkan kategori tinggi, sedang dan rendah.[13] Skala pengukuran dalam penelitian ini menggunakan skala Guttman Indikator penelitian ini di hitung menggunakan analisis univariat dengan t-test dengan menggunakan SPSS dalam bentung proporsi dan presentase .

Tabel 1. Faktor indikator kuesioner

\begin{tabular}{|c|c|c|c|}
\hline Konstrak & Faktor indikator & $\begin{array}{c}\text { Nomor } \\
\text { item }\end{array}$ & Butir \\
\hline $\begin{array}{c}\text { Antioksidan } \\
\text { dan radiasi } \\
\text { alam }\end{array}$ & $\begin{array}{c}\text { Pengetahuan } \\
\text { antioksidan } \\
\text { alami }\end{array}$ & $1-10$ & 10 \\
\cline { 2 - 4 } & $\begin{array}{c}\text { Pengetahuan } \\
\text { radiasi alam }\end{array}$ & $11-20$ & 10 \\
\cline { 2 - 4 } & \multicolumn{2}{|c|}{ Total } & 20 \\
\hline
\end{tabular}

Tabel 2. Tolak pengukuran pengetahuan dalam norma penilaian

\begin{tabular}{|c|c|c|}
\hline No. & Rentangan Norma & Kategori \\
\hline 1 & $\mathrm{x} \geq \mathrm{M}+\mathrm{SD}$ & Tinggi \\
\hline 2 & $\mathrm{M}-\mathrm{SD}<\mathrm{X}<\mathrm{M}+\mathrm{SD}$ & Sedang \\
\hline 3 & $\mathrm{X}<\mathrm{M}-\mathrm{SD}$ & Rendah \\
\hline
\end{tabular}

Keterangan : $\mathrm{X}=$ Skor $\mathrm{M}=$ Mean hitung $\mathrm{SD}=$ Stándar deviasi [13]

\section{IV.HASIL DAN PEMBAHASAN}

Kegiatan utama penyuluhan berupa pengolahan tanaman jagung yang dapat dikonsumsi sehari-hari sebagai antioksidan alami serta pengenalan radiasi alam yang dapat menjadi radikal bebas dalam tubuh. Selanjutnya setelah data terkumpul, data ditabulasi, diskor, dan dianalisis dengan bantuan softwere MS Exel diperoleh hasil penelitian skor minimum 13, skor maksimum 20, rata-rata 13,12 dan standar deviasi 2,83. Hasil kuesioner pre-test menunjukan sebelum ada penyuluhan sekitar $74,8 \%$ siswa kelas IV,V dan VI sudah mengenal mengenai antioksidan alami dan radon. Siswa belajar menanam dan mengolah jagung dari pendidikan kelas III dan membantu orang tuanya dalam mengolahnya menurut hasil wawancara guru SD setempat. Deskripsi hasil penelitian tersebut dapat dilihat pada tabel berikut

Tabel 3. Uji Validitas dan reabilitas kuesioner

\begin{tabular}{|c|c|c|c|c|c|}
\hline $\begin{array}{l}\text { Sub } \\
\text { Variabel }\end{array}$ & Pertanyaan & $\begin{array}{l}\text { Nilai } r \\
\text { Hitung }\end{array}$ & Reabilitas & $\begin{array}{l}\text { Titik } \\
\text { Kritis }\end{array}$ & $\begin{array}{l}\text { Keteran } \\
\text { gan }\end{array}$ \\
\hline \multirow{5}{*}{$\begin{array}{l}\text { Pengetahu } \\
\text { an } \\
\text { antioksida } \\
\mathrm{n} \text { alami }\end{array}$} & $\mathrm{P} 1$ & $\begin{array}{l}0.39 \\
9\end{array}$ & \multirow[t]{5}{*}{0.367} & \multirow[t]{5}{*}{0.3} & $\mathrm{~d} \quad$ Vali \\
\hline & $\mathrm{P} 2$ & $\begin{array}{l}0.36 \\
9\end{array}$ & & & $\mathrm{~d} \quad$ Vali \\
\hline & $\mathrm{P} 3$ & $\begin{array}{l}0.32 \\
0\end{array}$ & & & $\mathrm{~d} \quad$ Vali \\
\hline & P4 & $\begin{array}{l}0.32 \\
9\end{array}$ & & & $\mathrm{~d} \quad$ Vali \\
\hline & $\mathrm{P} 5$ & $\begin{array}{l}0.39 \\
2\end{array}$ & & & Valid \\
\hline
\end{tabular}




\begin{tabular}{|c|c|c|c|}
\hline \multirow{15}{*}{$\begin{array}{l}\text { Pengetahu } \\
\text { an radiasi }\end{array}$} & $\overline{\mathrm{P} 6}$ & $\begin{array}{l}0.37 \\
7\end{array}$ & Valid \\
\hline & P7 & $\begin{array}{c}0 . \\
306\end{array}$ & Valid \\
\hline & $\overline{\mathrm{P} 8}$ & $\begin{array}{l}0 . \\
314\end{array}$ & Valid \\
\hline & P9 & 0.340 & Valid \\
\hline & P10 & 0.380 & Valid \\
\hline & P11 & 0.305 & Valid \\
\hline & P12 & 0.449 & Valid \\
\hline & P13 & 0.394 & Valid \\
\hline & P14 & 0.347 & Valid \\
\hline & P15 & 0.490 & Valid \\
\hline & P16 & 0.356 & Valid \\
\hline & P17 & 0.358 & Valid \\
\hline & P18 & 0.311 & Valid \\
\hline & P19 & 0.498 & Valid \\
\hline & P20 & 0.315 & Valid \\
\hline
\end{tabular}

Tabel 5. Pengetahuan sebelum dan sesudah penyuluhan

\begin{tabular}{|c|l|c|c|}
\hline \multirow{2}{*}{$\begin{array}{l}\text { Interval } \\
\text { skor }\end{array}$} & kategori & presentase \\
\cline { 3 - 4 } & & Sebelum & sesudah \\
\hline $\begin{array}{c}\mathrm{X} \\
15,95\end{array}$ & Tinggi & $23.01 \%$ & $56.12 \%$ \\
\hline $\begin{array}{c}10,29< \\
\mathrm{x}<15,95\end{array}$ & Sedang & $74.80 \%$ & $93.88 \%$ \\
\hline $\begin{array}{c}\mathrm{X}< \\
10.29\end{array}$ & Rendah & $2.19 \%$ & $0 \%$ \\
\hline
\end{tabular}

Pengetahuan radiasi dan Antioksidan (Sebelum Penyuluhan)

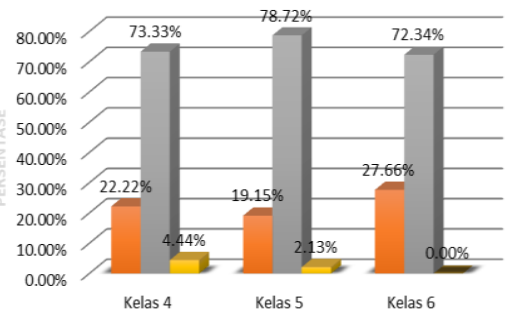

Gambar 1. Pengetahuan antioksidan dan radiasi sebelum penyuluhan

Pengetahuan radiasi dan Antioksidan (Setelah Penyuluhan)

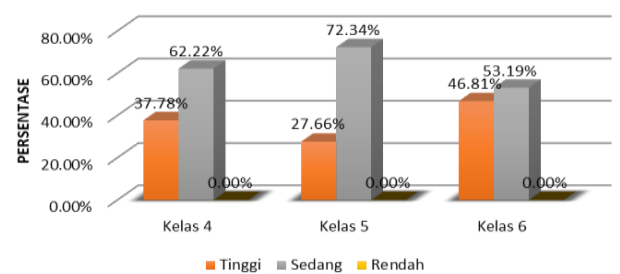

Gambar 2. Pengetahuan antioksidan dan radiasi sesudah penyuluhan
Setelah penyuluhan semua siswa telah mengenal dan tidak ada yang tidak mengetahui mengenai antioksidan alami dan radon ( pengetahuan rendah $0 \%$ ). Tujuan penyuluhan ini adalah untuk promosi kesehatan dalam upaya memelihara dan meningkatkan kesehatan mereka sendiri.[9], [14] Salah satu upaya dalam promosi kesehatan yang dapat mempengaruhi percepatan penyesuaian dan pengembangannya adalah efektif atau tidaknya metode penyuluhan yang diterapkan. Penyuluhan dengan prinsip edutaiment juga efektif dalam salah satu bentuk upaya dan intervensi yang mandiri untuk membantu responden baik individu, maupun masyarakat.[15] Salah satu strategi untuk memperoleh perubahan perilaku menurut WHO adalah promosi kesehatan dengan pemberian informasi untuk meningkatkan pengetahuan sehingga menimbulkan kesadaran dan dapat dilakukan dengan pemberian penyuluhan kesehatan. Pengetahuan diperoleh baik daripengalaman langsung maupun pengalaman dari orang lain.[9]

Pada hasil penelitian ini, pengetahuan terhadap paparan radiasi radon dan penanganannya berupa antioksidan sebelum penyuluhan paling rendah $2,14 \%$. Hal ini mengindikasikan bahwa masih ada siswa SDN yang masih belum mengeri akan mamfaat antioksidan dalam mengurangi bahaya paparan radiasi alam (radon). Akan tetapi, setelah penyuluhan tidak adanya responden yang tidak mengetahui akan bahaya radiasi dan antioksidan sebagai penanganannya. Hal ini mungkin terjadi akibat efektifitas paparan penyuluhan dan kondusifnya akan pelaksanaan kegiatan $\mathrm{Hal}$ ini perlu dilakukan kembali untuk membangkitkan kesadaran masyarakat akan pengetahuan ini sehingga dapat membentuk suatu tindakan atau perilaku seseorang.

Menurut Notoatmodjo (2011), bahwa perilaku hidup sehat pada dasarnya dibentuk memalui respon seseorang terhadap stimulus yang berkaitan dengan lingkungan.[16] [17]. Lingkungan adalah salah satu faktor yang mempengaruhi kesehatan manusia.[18] Salah satu usaha yang dilakukan manusia untuk menjaga kesehatan masyarakat supaya dapat mencapai derajat kesehatan yang optimal adalah dengan merubah lingkungan hidup menjadi lingkungan yang bersih.[8] Faktor ini akan bertahan lama jika suatu perilaku dasari pengetahuan dan kesadaran. Pengetahuan, pikiran, keyakinan memegang peranan penting dalam menentukan sikap dan diperlukan suatu kondisi yang memungkinkan yakni fasilitas dan dukungan.

Beberapa faktor lainnya yang dpat mempengaruhi derajat pengetahuan yaitu Umur. Semakin bertambahnya usia semakin meningkatnya 
pengetahuan karena lebih memudahkan dalam adaptasi terhadap sesuatu. [19] Akan tetapi penelitian ini pengetahuan anak SD kelas V dan III cenderung lebih tinggi dibandingkan anak kelas VI. Selain umur, pengalaman dan sosial budaya juga mempengaruhi tingkat pengetahuan yang dapat mempengaruhi sikap anak kedepannya. Pengalaman adalah pembelajaran yang tidak dapat terulang lagi yang dapat meningkatkan sikap dalam kehidupan sosial dan dapat membuka jalan informasi terhadap situasi lingkungan.[11], [16] Motivasi dan dukungan dari pihak orang tua juga mendorong pengetahuan dan sikap siswa sekolah dasar ini untuk menjadi lebih baik dalam memelihara kesehatannya.

Penelitian serupa yang telah dilakukan di SDN arjasari sebelumnya[16] akan tetapi terdapat perbedaan metode dan penyampaian pada responden. Metode ini lebih baik digunakan karena terlihat peningkatan dari penelitian sebelumnya yaitu sebanyak $41 \%$ responden masih kurnag dapat memahami pengetahuan akan radiasi alam. Sedangkan pada penelitian dengan metode edutaiment, responden menjadi lebih baik pengetahuanya sehingga di dapat hasil yang signifikan dan bermakna.

Dalam penelitian ini, penulis masih menyadari adanya kekurangan meskipun pelaksanaan penelitian diupayakan sebaik mungkin. Kelemahan tersebut antara lain: Pertama, subjek penelitian masih terlalu dini dalam menerima penyuluhan walaupun didampingi oleh orang tua/walinya. Kedua, kuesioner yang digunakan sebagai alat untuk mengukur pengetahuan, sikap dan perilaku yang dapat memunculkan kelemahan- kelemahan antara lain: recall bias antara pewawancara dan yang diwawancarai dan ketidakjujuran dalam memberi jawaban sehingga salah dalam menafsirkan pertanyaan. Oleh sebab itu hasil penelitian ini masih belum optimal. Ketiga dalam mengukur Hal tersebut dilakukan karena pertimbangan keadaan responden, waktu dan biaya penelitian.

\section{KESIMPULAN}

Kesimpulan dari penelitian ini adalah respon siswa terhadap pengenalan antioksidan alami dan radon sangat baik. Hal ini dipengaruhi oleh siswa tertarik dengan dalam radiasi alam dan pengolahan jagung yang dapat menjadi konsumsi dan tambahan penghasilan bagi kedua orang tuanya. Oleh karena itu, perlu dilakukan penelitian lebih lanjut untuk meningkatkan pengetahuan siswa tentang cara meningkatkan kualitas hidup baik secara ekonomi dan sosial. Penelitian masih terdapat kekurangan sehingga diperlukan penelitian selanjutnya mengenai perilaku dan promosi kesehatan di wilayah tersebut baik melalui media leaflet, poster atau ceramah dan faktor faktor yang mempengaruhinya yang sesuai dengan Radon Mitigation Program yang disesuaikan oleh EPA dan UNSCEAR.

\section{UCAPAN TERIMA KASIH}

Kami ucapkan terima kasih atas Kepala Sekolah SDN Arjasari, Direktorat Riset dan Pengabdian Pada Masyarakat Universitas Padjadjaran dan masyarakat yang telah membantu kegiatan ini.

\section{DAFTAR PUSTAKA}

[1] K. Sayuti and R. Yenrina, Antioksidan Alami dan Sintetik, 1st ed. Padang Indonesia: Andalas University Press, 2015.

[2] S. Kumar, "Free Radicals and Antioxidants: Human and Food System," Adv. Appl. Sci. Res., vol. 2, no. 1, pp. 129-135, 2011.

[3] M. J. P. Stuart C. White, "Oral Radiology Principles and Interpretation," Mosby, vol. 5th editio, no. 9, pp. 1689-1699, 2004.

[4] J. M. M. ; T. S. J. M. William J. Angell; Francesco Bochicchio; Susan Conrath; Sarah C. Darby; David Fenton; R. William Field;Alastair Gray;Thomas Jung; Michaela Kreuzer; Paul McGale Zielinski, Who Handbook on Indoor Radon - A Public Health Perspective. France: WHO Library Cataloguing, 2009.

[5] B. Sekarningrum and S. Sitam, "Environmental Health Condition and Community Healthy Behavior in the Radon Radiation Exposure Area," Rev. Integr. Bus. Econ. Res., vol. 7, no. 4, pp. 253-265, 2018.

[6] B. Sekarningrum, "The Social Economic Situation of Community Exposed to Radon Radiation in West Java Province," Rev. Integr. Bus. Econ. Res., vol. 6, no. 1, pp. 340-348, 2017.

[7] B. Y. Li et al., "Radon-induced reduced apoptosis in human bronchial epithelial cells with knockdown of mitochondria DNA," J. Toxicol. Environ. Heal. Part A Curr. Issues, vol. 75, no. 18, pp. 1111-1119, 2012.

[8] WHO, "Who Handbook on Indoor Radon - A Public Health Perspective," World Heal. Organ., 2009.

[9] S. Kumar and G. Preetha, "Health promotion: An effective tool for global health," Indian $J$. Community Med., vol. 37, no. 1, p. 5, 2012.

[10] R. A. Sianturi, "PENERAPAN METODE EDUTAINMENT DALAM PEMBELAJARAN MENULIS TEKS BERITA,” vol. 2, pp. 1-9, 2014.

[11] M. Notosiswoyo, "Pengetahuan, Sikap dan Perilaku Siswa SLTA dalam Pencegahan Kecelakaan Sepeda Motor di Kota Bekasi," J. Ekol. Kesehat., vol. 13, no. 1, pp. 1-9, 2014.

[12] K. Armani, Suhardi Marli, "METODE EDUTAINMENT UNTUK MENINGKATKAN KEMAMPUAN BERBICARA PADA SISWA DI SEKOLAH DASAR," Sungai Pinyuh Pontianak Indoneisa, 2014.

[13] Anas Sudijono, "Prof.-Drs.-Anas-SudijonoPengantar-Evaluasi-Pendidikan.-intro.pdf." PT Raja Grafindo Jakarta, Jakarta, 2003.

[14] M. Tellez, A. Zini, and S. Estupiñan-Day, "Social Determinants and Oral Health: An Update," Curr. Oral Heal. Reports, vol. 1, no. 3, pp. 148-152, 2014. 
[15] J. Genci, "Technological Developments in Education and Automation," pp. 10-11, 2010.

[16] A. A, S. Sitam, S. Susilawati, I. Satifyl, I. R. Octavia, and M. A. Damayanti, "Knowledge level of the elementary school of Arjasari students after education regarding natural background radiation and oral health care," Padjadjaran J. Dent., vol. 29, no. 3, pp. 172-176, 2017.

[17] N. Soekidjo, "Promosi Kesehatan Teori dan Aplikasi Edisi Revisi." p. 325, 2010.

[18] ATSDR/CDC, "Case Studies in Environmental Medicine: Radon Toxicity," Case Stud. Environ. Med., 2010.

[19] T. Indrawati, "Pengaruh Umur, Pendidikan, dan Pengalaman Bidan Praktik Swasta (BPS) Terhadap Pengetahuan Pertolongan Kegawatdaruratan Persalinan Di Wilayah Dinas Kesehatan Kota Semarang," J. Promosi Kesehat. Indones., vol. 4, no. 2, pp. 122-126, 2006. 